\title{
Ludwig Tieck's Herr Von Fuchs (1793) As the Perfect Embodiment of Romantic Irony*
}

\author{
Purificación Ribes Traver \\ Universitat de València
}

\begin{abstract}
This paper deals with a long forgotten German version of Volpone: Herr von Fuchs, written by the pre-Romantic playwright Ludwig Tieck in 1793 and unjustly neglected by editors, critics and theatrical directors alike. As an analysis of the play reveals, Herr von Fuchs is an accomplished and thought-provoking appropriation of a classical piece of drama which privileges the employment of Romantic irony as the best means to question widespread assumptions about political, educational, religious and aesthetic issues. It is the aim of this paper to grant Tieck's masterful example of creative translation the high recognition it deserves as a most accomplished German adaptation of Ben Jonson's Volpone.
\end{abstract}

KEYWORDS: Volpone, Tieck, Herr Von Fuchs, Romantic irony.

\section{Introduction}

Although Ludwig Tieck was the first German translator of Ben Jonson's Volpone, his most accomplished version has suffered from long, undeserved oblivion. Two factors, in my opinion, are responsible for this situation: the version's strong metatheatrical character and the success of Stefan Zweig's 1926 version of Volpone.

Considering the horizon of expectations of Tieck's audience, ${ }^{1}$ the cold reaction which his adaptation prompted from his

\footnotetext{
" Research for this essay was funded by Project FFI2008-02640-E/FILO.

${ }^{1}$ Jauss's "Erwartungshorizont" as defined in Literaturgeschichte als Provokation der Literaturwissenschaft (1970).
}

(E) ederi 20 (2010: 121-142)

https://doi.org/10.34136/sederi.2010.6 
contemporaries comes as no surprise, since, in 1793, they were unaccustomed to updates of classical texts as striking as Tieck's. Then, in the 1920s, when audiences became more receptive to Tieck's distancing techniques -as the success of his previously neglected Der gestiefelte Kater evidences- a new version of Volpone caught the public eye and became such an instant success that it rendered an unearthing of Tieck's own adaptation unnecessary.

In 1926 no one would have thought of a more suitable version of Ben Jonson's Volpone than Stefan Zweig's. His lieblose Komödie was performed in Austria, Germany and Switzerland and was soon adapted to the French stage by Jules Romains, who improved on Zweig's text and provided the Atelier with a promptbook which made Volpone famous in France and elsewhere. ${ }^{2}$

Under these circumstances no need was felt for a recovery of Tieck's eighteenth-century version of the play, even though it surpasses Zweig's adaptation in structural coherence, character development and subtlety of tone. Unlike in Zweig's version, the denouement of Tieck's adaptation does not come as a surprise; the characters do not experience sudden transformations and there is no sharp contrast between a prevailing oppressive atmosphere and a sunny happy ending with no place for poetic justice. Tieck's happy ending is in line with his tolerant approach to the characters' behaviour, in spite of each character receiving what he or she deserves. His version, moreover, retains Jonson's sharp criticism of avarice even though the punishment which his characters receive is in line with the play's amiable tone.

\section{Tieck's Free Version of Volpone}

Although Ludwig Tieck was but a university student at the time he completed his version of Jonson's satiric comedy, it is difficult to think of a text that could better meet the requirements of an ideal adaptation of a classical play. Tieck's was never a servile type of rendering but a wholly creative one which made the best possible

\footnotetext{
${ }^{2}$ For further information on the reception of Zweig's and Romains' versions see Ribes $(2007,2009)$.
} 
use of the excellent hypotext ${ }^{3}$ which Jonson had written almost two hundred years earlier. His Herr von Fuchs ${ }^{4}$ succeeded in bringing Jonson's text back to life by means of a thorough process of updating which resulted in an excellent text, from both a structural and a stylistic point of view.

That is why reading Tieck's version today becomes such a rewarding experience, for not only is its language elegant and clear, but it makes the best possible use of a structural element which most adaptors have tended to reduce or suppress: the play's secondary plot. As a matter of fact, Tieck succeeds in transforming that part which has often been omitted for the sake of clarity into a masterly exercise in Romantic irony which subtly echoes the key issues of the main plot. ${ }^{5}$

Irony, moreover, becomes in Tieck's hands a useful device to draw a critical reaction from the audience he addresses ${ }^{6}$ and, at the same time, helps him reach that desirable distance from his personal

\footnotetext{
${ }^{3}$ We follow Genette's well-known definition of the term hypotext in relation to his fourth type of transtextuality, which he calls hypertextuality (1982:11-12). To avoid confusion, he makes clear that his employment of the term hypotext differs from the meaning attached to it by Mieke Bal (1981). Genette says, "by hypertextuality I mean any relationship uniting a text B (which I shall call the hypertext) to an earlier text A (I shall, or course, call it the hypotext), upon which it is grafted in a manner that is not that of a commentary [...] It may yet be of a kind such that text $B[\ldots]$ is unable to exist, as such, without $\mathrm{A}$, from which it originates through a process I shall [...] call transformation" (1997:5).

${ }^{4}$ It was first published as Ein Schurke über den andern oder die Fuchsprelle. Ein Lustspiel in drey Aufzügen (1798) and later under the title Herr von Fuchs. Ein Lustspiel in drei Aufzügen nach dem Volpone des Ben Jonson (1829).

${ }^{5}$ In Szondi's view (1986:57-75), Tieck's comedies fulfil Schlegel's concept of irony because they disrupt the spectator's narrative illusion by having his actors (and, at times, his playwright too) step out of their usual roles.

${ }^{6}$ Christopher Norris (2009) aptly summarizes these features, which are essential to Romantic irony: "It is an attitude or ethos that calls everything into doubt, from utterer's intentions to our knowledge of the world as given (supposedly) through sensory acquaintance or the concepts and categories of reason. Such 'infinitized' irony -as distinct from its 'stable' or unproblematic varieties- aroused great interest among poet-philosophers in the early-to-mid-nineteenth century."
} 
viewpoint which, in Schlegel's view, was essential for a work of art to achieve universal validity. ${ }^{7}$

Tieck's interest in bringing his version close to his audience makes him place the action in 1793, that is to say, exactly at the time he was rewriting Jonson's comedy. ${ }^{8}$ His selection of important contemporary events -such as the French Revolution- and influential living writers, such as Goethe or Schiller, ${ }^{9}$ make it impossible for his German audience to ignore the theatrical -and, therefore, artificial- nature of the play. Its thematic concerns are thereby brought so close to the audience that they cannot abstain from taking sides with what they see, especially when the classical Socratic couple of eiron and alazon ${ }^{10}$ succeeds in drawing their intelligent -and knowing- smile. ${ }^{11}$

Tieck resorts to a mild type of irony while allowing his ridiculous, self-seeking, intransigent and boisterous characters free expression of their incontinent tongues, only to have them reduced to silence by those self-contained characters whose soft but clear

\footnotetext{
${ }^{7}$ According to him, "irony is, as it were, the demonstration of infinity, of universality, of the feeling for the universe" (1958-1995:18.128), since a literary work presents a limited perspective while it opens up the possibility of other perspectives.

${ }^{8}$ Fliege (Jonson's Mosca) and Herr von Fuchs (Volpone) joke about the duration of Herr von Fuchs' illness, which may extend into the following century, since it is already 1793: "[Fliege] Gott schenke Ihnen [...] [Herr von Fuchs] Und Gesundheit, um noch lange so krank zu bleiben. [Fl.] Daß Sie auch noch im künftigen Jahrhundert. [H. F.] Wir schreiben schon 1793, es ist nicht mehr sehr lange" [[Fliege] God give you [...] [Herr von Fuchs] And health, that my present illness lasts long. [Fl.] Even into the next century. [H. F.] We won't have to wait long. It is 1793 already] (1829:14).

${ }^{9}$ It is probably no mere coincidence that Tieck selected these two poets for this version where he reflects critically on the importance of a literary education, since, as Weiss underlines in his introduction to Schiller's Aesthetic Letters "the two poets are noteworthy as successful exponents of the two great elements of humanity, the real and the ideal $[\ldots]$ both were earnest seekers after truth: it was for both the very condition of their existence" (1845:viii-ix).

${ }^{10}$ The Oxford Dictionary of Literary Terms defines eiron as "a stock character in Greek comedy, who pretends to be less intelligent than he really is, and whose modesty of speech contrasts with the boasting of the stock braggart or alazon" (http://www.oxfordreference.com).

${ }^{11}$ It is no mere coincidence that Birnam, whose ideological bent Tieck fully shares, is only five years his younger, as we find out when Murner asks him his age (1829:3738), which makes his remarks fully meaningful to his audience and prevents their uncritical identification with what they see on stage.
} 
voices give full expression to Tieck's ideals of moderation and tolerance. Louise's voice -unlike that of Jonson's Celia- subtly, but firmly, reminds her greedy guardian Rabe (Jonson's Corvino) that he has no right to impose a husband on her or to waste her fortune. In the end she is free to offer her own hand to Karl von Krähfeld (Jonson's Bonario), and the Court of Justice declares her of age to take possession of her estate. Karl is also returned the fortune which his father, Herr von Krähfeld (Corbaccio) had greedily bequeathed unto the dying Herr von Fuchs (Volpone) in the hope of inheriting his whole fortune when he passed away. The young couple is allowed to administer those goods which their parents or guardians had misused in their own interest.

Unlike in Jonson's comedy, all harshness is removed from the play's denouement, and even the meanest characters receive a type of punishment which seeks their moral improvement. No one is lashed, sent to the galleys or confined in a damp prison.

This type of stern punishment, however, finds a place although merely imaginary- in Tieck's secondary plot, since Murner der Gelehrte (Murner the Learned, i.e. Jonson's Sir Politic) is ready to make use of the gallows and destructive fire in order to impose his ideal form of government on his prospective subjects. He has carefully designed an educational programme with no place for Philosophy, History of Art or Literature since, in his view, these disciplines go against social progress. However, it is not difficult to discover that what he really aims at is personal gain, achieved through the manual work of his uneducated and uncritical subjects. ${ }^{12}$

Paradoxically enough, this boisterous and intransigent wouldbe ruler is put to silence by a single voice, that of his wife, who not only makes him return to Germany against his own will, but even makes him write what he most detests, a poem. As Birnam -Jonson's Peregrine and Murner's eiron- teasingly remarks, that is the

\footnotetext{
${ }^{12}$ Murner's self-interested educational politics is a well-established practice, as Schiller reveals in his 1oth Aesthetic Letter: "There were men even in antiquity, who esteemed polite culture by no means a benefit, and therefore were strongly inclined to forbid the introduction of the imaginative arts into their republic. [...] How should they, who know no other measure of worth than the toil of acquisition and its palpable results, be capable of estimating the calm operation of taste upon the outward and inward man, while they regard the fortuitous disadvantages of polite culture, without its essential benefits" (1845:42; my italics).
} 
punishment which the Muses have imposed on him for having sinned against them.

It may not be mere coincidence that these very Muses are the ones which Tieck was about to serve for the rest of his life, since, after completing his Herr von Fuchs, he took the decision of becoming a professional writer. ${ }^{13}$ As personal records from this period show, his views on the importance of education were contrary to those of his character Murner der Gelehrte. As his free version of Volpone eloquently -and ironically- shows, he deemed education and literature essential to replace selfish despotism with generosity and tolerance.

\section{Tieck's Rewriting of the Secondary Plot: a Masterly Exercise in Romantic Irony}

Although Tieck's free adaptation of the main plot bears his personal mark, especially in the Romantic tone of its denouement and the strengthening of its main female character, his most original and valuable contribution is undoubtedly to be found in the secondary plot where Birnam (Jonson's Peregrine) assumes the Socratic role of the eiron by showing admiration for the eccentric arguments of Murner der Gelehrte (Jonson's Sir Politic), his Socratic alazon. Tieck deliberately avoids the dogmatic exposition of his beliefs to his audience. Instead, he allows his character Murner full freedom to voice his strong convictions while Birnam ironically pretends to share them.

Any spectator aware of Tieck's profound admiration for Shakespeare would soon find a close relationship between the name

\footnotetext{
${ }^{13}$ Tieck was well aware that society as a whole did not share the writer's range of values which were often considered too idealistic. That is why he told his friend Wackenroder, who would also devote himself to the fine arts, that what he most treasured was that which the world most despised. He addressed the following to Wackenroder on 30.11.1792: "Genau genommen solltest Du Dich ganz allein mit der Musick, und ich mit der Dichtkunst beschäftigen, denn die Welt ist wirklich nicht für uns, so wie wir nicht für die Welt, wir werden dort immer (ich leider wenigstens) ihre Wichtigkeiten unwichtig finden" [You should devote yourself wholly to the cultivation of music, and I to literature, because the world is truly not for us, in the same way as we are not for it. We, or I, at least, will always deem unimportant what the world considers important] (Wackenroder 1991:2.85-86; my italics).
} 
of his eiron and the misleading wood of Birnam which, as the witches had foretold, did come to Dunsinane: ${ }^{14}$

[Macbeth] I pall in resolution, and begin

To doubt th'equivocation of the friend,

That lies like truth. 'Fear not till Birnam wood

Do come to Dunsinane' and now a wood

Comes toward Dunsinane. $(5 \cdot 5 \cdot 40-44)$

The name of the Socratic alazon: Murner, ein reisender Gelehrte (Murner, a Learned Traveller), ${ }^{15}$ is also revealing of the character's personality and preferences. Tieck replaces the quality of "would-be politician" which he found in the Jonsonian character on which he modelled his own with that of an educated man who is proud of his knowledge. Tieck finds his source of inspiration for Murner der Gelehrte's deep educational convictions in Sir Politic Would Be's strong political opinions. While Sir Politic boasts of being acquainted with high political secrets: "I know the ebbs and flows of state" (II.i.104-105), Murner is persuaded that he would be the best ruler $^{16}$ his country could ever have.

\footnotetext{
${ }^{14}$ The fact that Tieck had recently attended a performance of the play in Nurnberg may have led him to choose this name for his subtle character. The remarks which he makes to his sister about the features of the version he had just seen on stage are most revealing of what he deemed fitting for an adaptation as well as what, in his view, should be avoided. As he tells his sister in a letter written in May 1793, Stephani's version lacked that self-restraint which was Tieck's permanent aim. He said: "Liebste Schwester, Ich bin schon in Nürnberg gewesen [...] Es war gerade eine Schauspielertrupppe da und sie spielten gerade Macbeth und gerade die Umarbeitung von Stephani, der du dich rege noch erinnern wirst, wir haben sie mehrmals auf dem kleinen Theater gespielt [...] Wenn nur die Umarbeitung selber nicht gar so kläglich wäre!" [Dear sister, I've just been to Nürnberg [...] A company was playing Macbeth, Stephani's free version, the one we used to perform at that tiny theatre [...] I'm sure you still remember [...] If only Stephani's version were less sensationalist!] (Markert 2003:353-354; my italics). Stephani's spirit was, in fact, contrary to Tieck's, who tended to suppress any scene whose sensationalism or violence could interfere with the play's thematic coherence.

${ }^{15}$ Both Sir Politic and Murner spend some time in a foreign country where they write down each single detail of their uninteresting lives, no matter how trivial they may be. Sir Politic thinks these notes are valuable for his political activities, whereas Murner means to use them to complete his books of travels which, in his view, are the only literary genre which should be cultivated.

${ }^{16}$ Murner is as ready to rule a kingdom as a republic, since, as he makes clear, their
rulers share a similar cunning use of rhetoric to manipulate their subjects. He says:
"Wenn ich König, oder Protektor, oder Dämagog wäre" [were I king, lord protector or
demagogue"] (1829:81; my italics).
} 
Ironically, all of Murner's plans aim to prevent the access of his prospective subjects to civilizing culture. He wishes to avoid their contact with Philosophy, Classic and Contemporary Literature, and any type of poetical composition which may spring from the contemplation of nature. What he wishes his subjects to develop is not their rational ability to analyze life critically but their blind acceptance of a political -and economic-programme which someone has designed for the nation's economic progress and well-being. Murner, aware of the increasing demands of the Industrial Revolution, has developed a complete programme of physical education so as to prepare his subjects for the type of manual work which they are expected to do in the future. His careful design does not omit the collaboration of a religious faction which forbids all scientific research into nature because, in their view, that would mean defying God's laws. Uncritical masses could then be asked to find their contentment in austerity and not to crave after superfluous goods. ${ }^{17}$ Even though Murner completes the presentation of his programme by saying that it is in line with the principles of the Enlightenment, ${ }^{18}$ it is not difficult to realize that it serves his own covetousness, in the same way as the oily words of Volpone's "friends" were only aimed at the engrossment of their own fortunes.

Murner thinks that his programme will favour the advancement of progress in his country and is persuaded that travel books can greatly contribute to it. According to him: "Die Reiselektüre gehört zur Aufklärung, zu den Fortschritten des Jahrhunderts" (1829:44). ${ }^{19}$

\footnotetext{
${ }^{17}$ Murner's careful design for his subjects is in line with the ironic presentation of uncritical and manipulable masses which Schiller makes in his 8th Aesthetic Letter where he describes them as follows: "Contented to escape the tedious toil of reflection, they willingly submit their ideas to the guardianship of others [...]. They embrace with eager faith the forms which the state and priesthood hold in readiness for this emergency" (1845:34; my italics).

${ }^{18}$ Although Murner insists that the aim of his educational programme is to spread the principles of the Enlightenment, the steps which he takes to enforce them immediately betray his complete ignorance of that set of principles which surrounded Tieck's education and upbringing in Berlin and which he never disdained, not even when he shared the new ideas of the early Romanticism. See Scholz (1965:128-181) for further information on the principles in which Tieck was educated at the Friedrichswerder Gymnasium in Berlin where Friedrich Gedike was headmaster.

19 "Travel books are part of the Enlightenment, they belong to the century's progress."
} 
That is why he feels proud of his own achievement: "Meine Reisebeschreibung, so kurze Zeit ich auch erst hier im Lande bin, ist doch schon einige Bände stark" (1829:38). ${ }^{20}$ The testimonies from the past are the books which Murner is intent on suppressing. The first volumes which he means to remove from the library's shelves are those from the Graeco-Roman tradition: "von allen systematischen Büchern, von allen Griechischen, Lateinischen und Hebräischen, ließe ich die Bibliotheken säubern" (1829:85-86) ${ }^{21}$ He also means to eliminate these books from the school curriculum. In his educational programme teachers will not be selected according to their knowledge of the Classics, but depending on whether they can jump on one foot or not, because physical education is the only discipline which future schoolboys should be trained in:

Statt Latein und Griechisch zu lernen, muß sich die Jugend auf Springen und Laufen legen [...] Die Lehrer in den Schulen müßten nach der Höhe rangirt werden, in der sie springen könnten; statt daß oft manche von den berühmtesten unsrer jetzigen Gelehrten nicht auf einem Bein stehen können. (1829:86) ${ }^{22}$

Murner is ready to ban the development of any discipline which might interfere with his educational programme. That is why he declares that philosophers will be sent into exile because Philosophy has the dangerous effect of favouring independent thought. ${ }^{23}$ In Murner's own words,

\footnotetext{
20 "My report is already several volumes long, even though I've only been here for a short time."

21 "I would clean libraries of all systematic books, particularly those related to the Hebraic, Greek and Latin cultures." It is difficult not to recall Goethe's deep admiration for the Classics, as expressed in his journal Die Propyläen (1788-1790), where he spoke of the superiority of the ancients to the moderns.

22 "Young people should not be taught Latin and Greek, but jumping and running. School teachers should be valued according to their ability to jump high. It is regrettable that some of our best known scholars today cannot even stand on one foot."

${ }^{23}$ Murner's views on the dangerous nature of Philosophy ironically contrast with Schiller's emphasis on its civilizing role. He highlights his viewpoint by means of the following rhetorical questions: "Shall philosophy retire then from this sphere, dejected and despairing? [...] Will the conflict of blind forces endure forever in the political world, and hostile selfishness never succumb to social law?" and stresses its positive achievement as follows: "the spirit of free enquiry has destroyed the false conceptions, which long obstructed the passage to truth, and has undermined the foundation on which fanaticism and fraud had reared their throne" (Schiller 1845:32-33).
} 
Wer in meinem Lande philosophiren wollte, der würde über die Gränze gebracht [...] Ich es verbieten ließe, daß irgend jemand philosophirte [...] das führt geradehin zum Ruin des menschlichen Verstandes [...] Die Philosophie geht recht darauf aus, die eigne freie Meinung aufzuheben. $(1829: 83)^{24}$

He speaks of a new and genuine type of Philosophy which, according to him, consists of leaving man's natural ability to reason untouched. ${ }^{25}$

He is determined not to allow any process of reasoning to interfere with what he deems man's most precious treasure: his ability to experience sensations. That is why he thinks strong feelings to be the essential quality of scientific research: "Ein starkes Gefühl in einer Wissenschaft ist mehr Werth, als hundert auseinandergesetzte Gedanken" that is to say, "ohne sich über irgend etwas in tiefsinnige Spekulationen einzulassen" (1829:82$83){ }^{26}$

According to him, man should not attempt to look into the essence of things but merely perceive their outward appearance: "Man sehe die Bäume und Berge an, wie sie sind, und nicht, wie sie sein könnten" (1829:86) $)^{27}$ because that would be an act of defiance

\footnotetext{
24 "Whoever wished to philosophize in my land, him would I have banished [...] Philosophy would be forbidden because it ruins human reason [...] and favours independent thought." Schlegel's viewpoint on the disruptive character of Philosophy matches Tieck's ironical presentation of its revolutionary nature. Schlegel (1797:42) combined Fichte's concept of "freies Selbstdenken" [freedom to think for oneself] with the idea of political freedom which could be fostered by Philosophy, "the actual homeland of irony."

${ }^{25}$ As he puts it, "Der grade Menschenverstand, den jeder mit auf die Welt bringt, das ist die wahre Philosophie" (1829:83).

26 "In scientific research, strong feelings should be preferred to a hundred thoughts [...] without allowing profound speculation to interfere with it." Tieck's irony here becomes even more apparent if we recall Schiller's opinion on the need to overcome natural laziness with education: "Energy of spirit is requisite to overcome the obstructions which faint-heartedness as well as the indolence of nature oppose to education. The goddess of wisdom [...] at her very birth [...] was to maintain a hard contest with the senses, who will not be torn from their sweet repose" (1845:33; my italics).
}

27 "Man should contemplate mountains and trees as they are, not wonder what they could have looked like." 
against his Creator: "Der Mensch muß nicht klüger sein wollen, als sein Schöpfer" (1829:86). ${ }^{28}$

All these arguments reveal Murner's wish to deprive his subjects of a critical spirit which might lead them to question his form of government. That is why he forbids his subjects free access to any kind of literature which might imaginatively create a reality different from the one they know. According to him, it is often the case that writers of this pernicious type of literature have a good command of such contaminating subjects as Philosophy and Classical Literature, usually acquired at the most execrable of institutions, the University.

He has such tender care for the mental health of his subjects that literary composition would be declared unlawful in his kingdom: "Wer sich nun gar erfrechte, einen Roman oder eine Komödie zu schreiben, der würde ohne Barmherzigkeit aufgehängt" (1829:84) ${ }^{29}$ since "Schriftsteller [...] werden auf den verwünschten Universitäten gebildet, die $\mathrm{zu}$ nichts dienen, als unsre Jugend $\mathrm{zu}$ verderben" (1829:82)..$^{30}$

That same zestful ruler who is ready to have any writer of imaginative literature hanged, is determined to use the same purifying method to suppress any trace of visual forms of art, from paintings to engravings: "Alle Kupferstiche und Gemäldesammlungen ließe ich verbrennen" (1829:86)..$^{31}$

Murner thinks so highly of his methods that he believes the French Revolution should imitate them. He regrets that, although four years have already passed since its outbreak, not all the books from the French libraries have been thrown into the sea. As he tells Birnam: "Sehen Sie nur das Frankreich an [...] Vier Jahr Revolution, und noch sind die gelehrten Folianten und Quartanten, die Gedichte

\footnotetext{
28 "Man should not wish to know more than his Creator."

29 "Whoever dared write a comedy or a novel, he would be hanged."

30 "Writers [...] are instructed in those wicked universities which are good for nothing except the corruption of the youth."

${ }^{31}$ "I would throw every single engraving and painting collection to the flames."
} 
und Romane, nicht ins Meer geworfen [...] heißt das eine Revolution?" (1829:81). ${ }^{32}$

Murner seems to feel a profound aversion to any testimony of the past which might remind him of the historical importance of literary texts. That is why he takes measures not only to remove them from the libraries but also to prevent any text of this type from being stored in the libraries of his future kingdom. Aware of the importance of education for a cultural tradition to survive, he forbids the teaching of the Classics at schools and universities: "Zuerst vernichtete ich mit einem Schlage meines Zepters alle Universitäten, alle Schulen, wo man noch and die Alten dächte" (1829:82). ${ }^{33}$

Confident of his own experience as a university student, Murner says: "Ich weiß es aus eigener Erfahrung, wie wenig man dort lernt" (1829:82), ${ }^{34}$ an affirmation which leads Birnam to remark: "Ich traue Ihnen sehr viel Erfahrung zu" (1829:82). ${ }^{35}$

Murner's bottomless ignorance (which not even the university has been able to reduce) is given full expression in his detailed exposition of his ground-breaking cultural programme. When Birnam asks him about his plans for the theatre: "Mit den Theatern?" (1829:85). ${ }^{36}$ Murner proudly describes a type of spectacle which closely resembles a fighting contest. He says: "Ich machte nämlich große Übungsplätze daraus, [...] wo alle Arten von Leibesübungen, Springen, Balgen, Laufen, getrieben würden" (1829:85). ${ }^{37}$

The most valuable qualities expected from the actors of this peculiar type of spectacle are strong fists and large backs so that they may exchange blows at leisure: "Jedem, der ein paar gute Fäuste, und einen mäßigen Rücken hätte, wäre die freie Entree vergönnt"

\footnotetext{
32 "Look at France, for example [...] Four years of revolution and not all the erudite Folio and Quarto editions, the histories and novels have been thrown to the sea. Is that a true revolution?"

33 "With a blow of my sceptre I would annihilate all those schools and universities where one could still think of the Classics."

34 "My own experience has taught me how little one can learn there."

35 "I have no doubt that you're talking from experience."

36 "Have you got any plans for the theatre?"

37 "I would turn them (the playhouses) into large training places for the practice of jumping, running or boxing."
} 
(1829:85). ${ }^{38}$ Murner ends his exposition by showing complete confidence that his dream of a National Theatre will finally come true: "Dann könnte man erst von Nationaltheatern sprechen!" (1829:85; my italics). ${ }^{39}$

Tieck's ironical handling of this issue will not go unnoticed if one recalls Lessing's opinion about the obstacles which a future National Theatre had to overcome before it could be established. As he pointed out in his Hamburgische Dramaturgie, it would require a higher cultural level in its potential audience, who, so far, had proved too lazy to achieve it (qtd. Berghahn 1997:528).

Murner, however, replaces the intellectual education of potentially dissident subjects with manual training which makes them fit for the factories: "Wer mir nicht ein Handwerk gelernt hätte, er sei Graf oder Bettler, der käme als ein Landstreicher ins Arbeitshaus. Fabriken und Handwerker sollten floriren, daß es eine Freude wäre" (1829:87). $\cdot^{40}$

As we have seen, Murner wants his state to be highly competitive. That is why he provides his subjects with the tools to achieve this end: he strengthens their muscles by means of a thorough training which they start at an early age and makes sure that they engage in no intellectual activity whatsoever. At the same time, he removes all traces of a past whose literary and artistic records might attest to its intellectual life and includes a moral programme that aims at teaching his subjects austerity: "Damit sich das Volk von der Schätzung der Nebensachen entwöhnte, müßten alle Prediger beständig in rothen Röcken gehn" (1829:87). ${ }^{41}$

\footnotetext{
38 "Anyone in possession of a good pair of fists and a strong back would be allowed free entrance to the theatre." It is moving to see the pains which Murner takes to look after his subjects. He shows such concern for their physical well-being that he intends to use part of his profits in any medical treatment which the "actors" which he has incited to fight may later require: "Das (so) eingekommene Geld aber würde auf die gewandt, die bei den Spielen etwa beschädigt würden" [money thus collected would be used to assist those who had been hurt during the games] (1829:85).

39 "We could then speak of a National Theatre."

40 "Whoever had not learned a trade -be it an earl or a beggar- he would be taken for a beggar and sent to a workhouse. It would be a pleasure to see factories and workers flourish."

41 "All parsons should wear red in order to help people disparage superfluous things." He also takes all the measures necessary to prevent frivolous behaviour from
} 
Tieck culminates his ironical presentation of Murner's cultural and educational programme by having him conclude that its implementation will foster the advancement of the Enlightenment in his country: "Die Aufklärung sollte in meinem Staate Riesenschritte thun" (1829:87)..$^{42}$ It is impossible not to smile at Murner's words when recalling Kant's definition of the movement: "Was ist Aufklärung? Sapere aude! Habe Mut, dich deines eigenen Verstandes zu bedienen!" (2004:9). ${ }^{43}$

Murner's statement sounds doubly ironical when bringing to mind Beiser's convincing argument (1992:9) that "The Aufklärung was essentially practical and, broadly speaking, a political movement [whose] fundamental aim [...] was to enlighten or educate the public, to make it aware of its civic rights and duties [...] In other words, its objective was the emancipation of the public, its liberation from the shackles of tradition, superstition, and despotism."

Having listened to Murner's wholehearted admiration for the Enlightenment, Tieck's audience can only smile at Murner's radical condemnation of reason and his enthusiastic defence of sensorial perception, especially when realizing the important role that it played in the advancement of the French Revolution. Tieck, like

flourishing among his beloved subjects. He decrees "Wer sich schminkte, oder die Lippen und Augenbraunen färbte, würde gebrandmarkt" [whoever uses makeup, lipstick or eye shadow, he will be branded] (1829:88). His zeal will no doubt foster that Calvinistic spirit which encourages hard work.

42 "Enlightenment would greatly advance in my state."

43 "What is Enlightenment? Sapere aude! Have the courage to use your reason! Dare to know!" Kant, fully convinced of the usefulness of a sound knowledge of the Classics, follows Horace's advice in his Epistles (I.2.40) and renders it literally in Latin: Sapere aude! He shares his view that the highest legacy which man can receive from knowledge is his ability to reason autonomously.

Horace's reflection on the importance of study for man's moral improvement resounds in Tieck's Herr von Fuchs, particularly in Murner's grotesque rejection of education and culture. According to Horace, "Et ni/ posces ante diem librum cum lumine, si non/ intendes animum studiis et rebus honestis,/invidia vel amore vigil torquebere" [unless you ask for a book and a lamp before daybreak; unless you devote yourself to fruitful study and honest deeds, envy and ill-will will keep you awake at night] (II.35-37; my italics).

Schiller similarly shared Horace's maxim, as evidenced in his 8th Aesthetic Letter (1845:33) where he says: "An ancient sage has detected it, and it lies concealed in the significant expression, sapere aude. Dare to be wise." 
most of his young contemporaries, at first had thought that the French Revolution would bring about true spiritual freedom. This is the view which he had expressed in a letter written to Wackenroder late in 1792: “O, wenn ich izt ein Franzose wäre! Dann wollt' ich nicht hier sitzen, dann [...] Doch leider bin ich in einer Monarchie geboren, die gegen die Freiheit kämpfte, unter Menschen, die noch Barbaren genug sind, die Franzosen ganz zu verachten" (II.161; qtd. Zeydel 1935:12). ${ }^{44}$ However, the excesses of the French Revolution made him realize that no revolution could succeed in any country unless preceded by a thorough education and enlightenment of its people.

Although, as we have seen, Murner's educational programme has nothing in common with the principles of the Enlightenment, it also falls outside of the Sturm und Drang, in spite of the emphasis which this movement places on feeling. What is more, Murner even says that the search for a deeper knowledge of nature would be an act of defiance against God, but anyone acquainted with Herder's principles would be aware of the emphasis he had placed on the poet's creative transformation of nature which turned him into a second creator. As he says in his Sämtliche Werke, "Poetry is no longer an imitation of nature but an imitation of the creative, name-giving Godhead [...] the poet becomes a second creator, poietes, maker" (xii; qtd. Berghahn 2005:534; my italics).

Any perceptive reader would also discover echoes of Rousseau's philosophy in that educational programme which highlights the importance of feelings. It would not be difficult for him to establish connections between his Emile (ou De l'education) (1762), a work which Goethe termed "Naturevangelium der Erziehung" and the outbreak of the French Revolution, which was rejected not only by Goethe but also by Tieck. ${ }^{45}$

\footnotetext{
44 "Oh, if I were now a Frenchman! I would not be sitting here, [...] But unluckily I was born in a monarchy which has fought against liberty, among men who are still barbarian enough to despise the French."

${ }^{45}$ Paradoxically enough, Rousseau's Emile would be consigned to the flames both in Paris, where it was first printed, and in Amsterdam, where it appeared a little later. Its author had to flee his country to avoid arrest and his Dutch printer, Jean Néaulme, was issued with a publication ban at the end of July 1762 .
} 
Tieck's farewell to his sister in a letter addressed to her in 1793 reveals his opposition to the French Revolution. News from France under Robespierre fill Tieck with such terror that he equates the Jacobins with the legendary Turkish threat. He says: "Gott gebe uns bald Frieden im deutschen Reich $\mathrm{u}[\mathrm{nd}]$ beschütze uns und unsre heilige Religion gegen Türken und Jacobiner" (Markert 2003:355).$^{46}$

Goethe's attitude towards the French Revolution cannot be considered any more favourable than Tieck's, since he does not even accept it as a means to achieve a National Literature. As he says in Literarischer Sansculottismus, "Wir wollen die Umwälzungen nicht wünschen, die in Deutschland klassische Werke vorbereiten könnten." ${ }^{47}$

Goethe, like Tieck, is more favourable to that spiritual type of revolution which -as he explains in the Propylaea- only true art can bring about: "Although the artist remains bound to nature and reality, the work of art, as product of the human spirit, goes beyond nature $[\ldots]$ true art transcends nature, lending it depth and significance" (qtd. Berghahn 2005:537).

Goethe's belief in the capacity of true art to transcend the limits of nature is also shared by Schiller, who showed his confidence in its capacity to illuminate the path to a better and more humane future..$^{8}$

The decision which Tieck took up around this time to devote himself wholly to the composition of literary works is the greatest proof that he completely shared Goethe's and Schiller's optimistic view of the transforming power of literature.

Like Schiller, Tieck was persuaded that literary works of a universal validity could only be achieved if the author distanced himself from his work of art. As Schiller put it, "the quality of poetry depends on the poet's artistic ability to distance himself from his

\footnotetext{
$4^{6}$ "God bless our German kingdom with peace and protect us and our holy religion against the Turks and the Jacobins."

47 "We do not want for Germany those political upheavals which might prepare the way for Classical works."

${ }^{48}$ As he puts it in his 9 th Aesthetic Letter, "Al political improvement should result from nobility of character [...] We must then find an instrument for this design [...] This instrument is the fine arts" (1845:35; my italics).
} 
personal experiences and to transform his subjective emotions into universal human feelings" (qtd. Berghahn 2005:544; my italics).

And, like some of his contemporaries, Tieck realized that irony was the best means to achieve this end, since, in Solger's view, irony was a transcendental means of contemplative enthusiasm, a union of impulse and rational lucidity (Wimsatt 1957:380). Irony, in Tieck's own words, "[Es] ist das Göttlich-Menschliche in der Poesie [...] Sie ist die Kraft, die dem Dichter die Herrschaft über den Stoff erhält" (Köpke 1855:II.238-239; my italics). ${ }^{49}$

This aspiration of harmonizing imagination and reality, ${ }^{50}$ which, as one of Tieck's biographers notes, marked his whole literary life, ${ }^{51}$ can be best symbolized in the painting of the Madonna whose contemplation filled him with enthusiasm when he saw it in 1793 (Littlejohns 1985). The painting was attributed to Raphael and Tieck went to Pommersfeld to see it. His detailed exposition of its aesthetic qualities fully reflects his own ideal. As he tells his sister Sophie in a letter:

Ich habe mich dort außerordentlich gefreut, ich habe [auch] ein Original von Raphael gesehen, es war göttlich, so ein schönes Ideal und doch so individuell [so einzig, so charakteristisch alle Züge], die höchste Ruhe der reinste Schönheit und doch Sprache und Geist in jeder Muskel der Madonna u[nd] ihres lieben Kindes. (Markert 2003:354; my italics) ${ }^{52}$

\footnotetext{
49 “[Irony] brings together the divine and the human in a poem [...] It gives poets whole control over their matter."

${ }^{50}$ This elusive synthesis of imagination and reality, moreover, is one of the defining marks of the early Romanticism and is inherent in the concept of "Romantic irony," which entails an imaginative perception of reality, since the reality which can be perceived through the senses is nothing but appearance. The true reality lies hidden behind it and can only be intuitively grasped with the help of fantasy. Schiller's advice

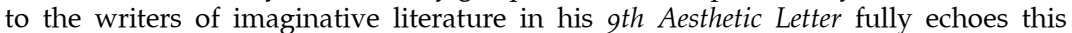
principle: "Invest them [your contemporaries] with the symbols of all that is excellent till reality bends to the ideal, and nature to art" (1845:40; my italics). For further details on the centrality of fantasy see Silvio Vietta (1983:208-221).

${ }^{11}$ In Paulin's words, “oft scheint es, als habe Tieck bewußt eine Kongruenz von Imagination und Realität angestrebt" [it often seems that Tieck is trying to harmonize imagination and reality] (1987:17; my italics).

52 "I have seen a painting by Raphael. It was so beautifully ideal and, at the same time, so real; there was harmony in its purest beauty and also life and energy in every muscle of the Madonna and her child."
} 
The clearest proof of Tieck's identification with this ideal which brings together the human and the divine is the fact that he signs the letter he addresses to his sister as "Tieck, vulgo. Raph[a]el." One could not think of a better way of showing his deep admiration for this artistic creator who embodied his aesthetic ideal.

Tieck's admiration for the Madonna was so strong that he paid two more visits to the art gallery in Pommersfeld that same year. His interest in the visual arts made him also attend Johan Dominik Fiorillo's lectures on History of Art at the University of Göttingen. ${ }^{53}$ This evidence of his love for the fine arts makes Murner's plans for his future realm doubly ironical, since, as he tells Birnam, he has the intention of burning all the collections of paintings and engravings which he might find in his hypothetical realm or republic.

Murner's plans concerning engravings sharply contrast with Tieck's great fondness for this form of art. It is most significant that in August 1794 he asked his brother "der Künstler" to engrave a design of Shakespeare for him. These are the words he wrote to Sophie: "Frage doch den Künstler einmal, ob er nicht nach einem Kupferstich eine gute Büste machen könne, wenn das geht, so soll er mir in Berlin den Shakespeare abgiessen. Ich wünsche, daß es möglich wäre" (Markert 2003:355). ${ }^{54}$

It is no mere coincidence that he wished to have an engraving of Shakespeare, as he had devoted three university terms to an intensive study of his work (Gillies 1936:206-207). Jeremias David Reuss (1750-1837), professor of Literature and librarian at the University of Göttingen, had supervised his study and had allowed him to borrow some of the valuable manuscripts which the university library kept. ${ }^{55}$

It was from this same -and well-known- library that he also borrowed Peter Whalley's 1761 seven-volume edition of Ben

\footnotetext{
53 He was the author of the famous Geschichte der zeichenden Künste von ihrer Wiederaufhebung bis auf die neuesten Zeiten (1798) (Markert 2003:337-338).

54 "Please ask the artist if he could copy a good bust from an engraved plate and, if so, ask him to carve a Shakespeare for me in Berlin. I wish it were possible."

55 As Tieck says in one of his lettters: "Ich habe ein paar alte Manuscripte von der hiesigen Bibliothek auf mein Zimmer, die ich etwas studiere" (Brief 1, Markert 2003:355) [I am now studying a couple of manuscripts from the library, which I have got in my bedroom].
} 
Jonson's Works. He studied it thoroughly and, with Eschenburg's help, was able to acquire the costly 1692 Folio edition of the Works, as he states at the back of its third blank page: "Diese Ausgabe des B.J. besitze ich schon seit dem Herbst 1793; Eschenburg hatte sie mir mit andern Engl. Büchern von London kommen lassen" (Fischer 1926a:103). ${ }^{56}$

One can easily imagine his impatience during the time he had to wait for this precious consignment. He must have feared that an untimely shipwreck might put an end to his dreams. Fortunately, the excesses of the French Revolution did not succeed in throwing his Folio and Quarto editions into the sea -as Murner would have wished for those in his realm- but he had the opportunity of studying them in such detail that, in Fischer's words, he became "einer der besten Ben Jonson-Interpreten seiner Zeit und jedenfalls der beste Ben Jonson Kenner in damaligen Deutschland" (1926a:131; my italics). ${ }^{57}$

Tieck's high level of exigency was not limited to the rigorous analysis of his sources but was also a working principle of his magnificent adaptations, whose aim was to give new life to the testimonies of the past. Romantic irony came to his help as the most effective device to keep the interest and critical awareness of his audience alive. This feature, together with the play's benign humour, spotless structure and perfect command of the language, make this version a delicate and rare dish for the most demanding palates.

\section{References}

Bal, Mieke 1981. "Notes on Narrative Embedding." Poetics Today 2/2: 41-59.

Baldick, Chris 2009. The Oxford Dictionary of Literary Terms. Oxford Reference Online. Oxford University Press.

<http:/ / www.oxfordreference.com >

\footnotetext{
56 "I own this edition of Ben Jonson since the autumn of 1793. Eschenburg had it brought to me from London, together with some other books." Tieck's high esteem for books can be evidenced in the splendid library which he left at his death. See Zeydel (1927:21-25).

57 "One of the best German critics of Ben Jonson at the time; the scholar with the deepest knowledge of his work."
} 
Beiser, Frederick C. 1992. Enlightenment, Revolution, and Romanticism. The Genesis of Modern German Political Thought 1790-1800. Cambridge, Massachussets: Harvard University Press.

Berghahn, Klaus L. 2005 (1997). "German literary theory from Gottsched to Goethe." Ed. H. B. Nisbet and Claude Rawson. The Cambridge History of Literary Criticism. Vol.4: The Eighteenth Century. Cambridge: Cambridge University Press: 522-545.

Fischer, Walther 1926a. "Zu Ludwig Tiecks elisabethanischen Studien: Tieck als Ben Jonson Philologe." Jahrbuch der deutschen Shakespeare Gesellschaft 62: $98-132$.

Fischer, Walther 1926b. "Ludwig Tiecks Shakespeare." Die neueren Sprachen 34: 102-108.

Genette, Gérard 1982. Palimpsestes. La littérature au second degré. Paris: Éditions du Seuil.

Genette, Gérard 1997. Palimpsests. Literature in the Second Degree. Trans. Channa Newman \& Claude Dobinsky. Lindoln \& London: University of Nebraska Press.

Gillies, Alexander 1936-1937. "Ludwig Tieck's English Studies at the University of Göttingen, 1792-1794." Journal of English and German Philology 36: 206-207.

Goethe, Johann Wolfgang v. 1795. Litterarischer Sanscülottismus $<$ www.Wissen-im-Netz.info $>$.

Goethe, Johann Wolfgang v. 1910 (1788-1790). Propyläen Ausgabe von Goethes sämtlichen Werken. Vol. 6. Munich: Georg Müller.

Herder, Johann Gottfried von 1994-1995 (1877-1913). Sämtliche Werke. Ed. Bernhard Ludwig Suphan. 33 Vols. Hildesheim: Georg Olms.

Herford, C.H. and Percy and Evelyn Simpson 1925-1952. Ben Jonson IX. Oxford: Clarendon Press.

Horati Flacci, Q. 1995. Opera. Ed. Shackleton Bailey. Leipzig: B.C. Teubner.

Horati Flacci, Q. 2001. The Epistles of Horace. Trans. David Ferry. N. York: Farrar Straus Giroux.

Jauss, Hans Robert 1970. Literaturgeschichte als Provokation der Literaturwissenschaft. Frankfurt: Suhrkamp.

Kant, Immanuel 2004 (1784). "Beantwortung der Frage: Was ist Aufklärung?" Ed. Erhard Bahr. Was ist Aufklärung. Stuttgart: Philipp Reclam: 9-17. [originally published in Berlinische Monatschrift (1784) 4: 481-494]

Köpke, Rudolf, ed. 1855. Ludwig Tieck: Erinnerungen aus dem Leben des Dichters nach dessen mündlichen und schriftlichen Mittheilungen. Leipzig: Brockhaus. 
Lessing, Gotthold Ephraim 1998 (1767). Hamburgische Dramaturgie. Stuttgart: Reclam.

Littlejohns, Richard 1985. "Die Madonna von Pommersfelden. Geschichte einer romantischen Begeisterung." Aurora 45: 163-188.

Lüdeke, Henry 1922. Ludwig Tieck und das alte englische Theater. Ein Beitrag zur Geschichte der Romantik. Frankfurt am Main: Diesterweg.

Markert, Heidrun 2003. “'Shakespeare, W[ackenroder] u[nd] die Natur umher machen mich sehr glücklich', zwei ungedruckte Briefe Ludwig Tiecks aus der Entstehungszeit der Romantik." Ed. Heidrun Markert. 'Lasst uns, da es uns vergönt ist, vernünftig seyn!'. Ludwig Tieck (1773-1853). Bern: Peter Lang. 331-357.

Norris, Christopher 2009. "Irony, Romantic." The Oxford Companion to Philosophy. Oxford Reference Online. Oxford University Press. <http://www.oxfordreference.com>

Paulin, Roger 1987. Ludwig Tieck. Stuttgart: J.B. Metzler.

Ribes Traver, Purificación 2007. "Stefan Zweig's Volpone, eine lieblose Komödie on Stage in Austria and Germany (1926-1927)." The Ben Jonson Journal 14/1: 61-78.

Ribes Traver, Purificación 2009. "Early Stage History of Jules Romains' Volpone." Sederi 19: 121-151.

Romains, Jules 1928. Volpone. En collaboration avec Stefan Zweig d'après Ben Jonson. Paris: Les Oeuvres Libres.

Rousseau, Jean-Jacques 1995 (1762). Emile, ou de l'éducation. Paris: Gallimard.

Schiller, Friedrich 1782. "Uber das gegenwartige deutsche Theater." WerkePhilosophische Schriften. <www.wissen-imNetz-info>

Schiller, Friederich 1845. The Aesthetic Letters and the Philosophical Letters of Schiller. Trans. \& intr. J. Weiss. Boston: Charles C. Little and James Brown.

Schlegel, Friedrich V. and J.F. Reichardt, eds. 1797. Lyceum der schönen Künste. Berlin: Johann Friedrich Unger. Vol. 1 .

Schlegel, Friedrich 1958-1995. Kritische Friedrich-Schlegel-Ausgabe. Ed. Ernst Behler. Paderborn: Schöningh.

Scholtz, Harald 1965. "Friedrich Gedike (1754-1803). Ein Wegbereiter der preußischen Reform des Bildungswesens." Jahrbuch für die Geschichte Mittel- und Ostdeutschlands 13-14: 128-181.

Shakespeare, William 1997. Macbeth. London: Norton.

Szondi, Peter 1986. "Friedrich Schlegel and Romantic Irony, with Some Remarks on Tieck's Comedies." Trans. Harvey Mendelsohn. On Textual Understanding and Other Essays. Manchester: Manchester University 
Press. 57-75. ["Friedrich Schlegel und die romantische Ironie: Mit einer Beilage über Tiecks Komödie." Euphorion 48 (1954): 397-411]

Tieck, Ludwig 1798 (1793). Ein Schurke über den andern oder die Fuchsprelle. Ein Lustspiel in drey Aufzügen. Berlin: Langhoff.

Tieck, Ludwig 1829. Herr von Fuchs. Ein Lustspiel in drei Aufzügen nach dem Volpone des Ben Jonson. Schriften vol. 12. Berlin: G. Reimer.

Tieck, Ludwig 1964 (1797). Der gestiefelte Kater. Kindermärchen in Drei Akten mit Zwischenspiele, einem Prologe und Epiloge. Ed. Helmut Kreuzer. Stuttgart: Philip Reclam Jun.

Vietta, Silvio 1983. "Der Phantasiebegriff der Frühromantik und seine Voraussetzung in der Aufklärung." Ed. Silvio Vietta. Die literarische Frühromantik. Göttingen: Vandenhoeck und Ruprecht: 208-221.

Wackenroder, Wilhelm Heinrich 1991 (1792). Sämtliche Werke und Briefe. Eds. Silvio Vietta and Richard Littlejohns, 2 vols. Heidelberg: Lambert Schneider.

Wimsatt, K., Wimsatt Jr. and Cleanth Brooks 1970 (1957). Romantic Criticism. Vol. 3 of Literary Criticism. A Short History. London: Routledge and Kegan Paul.

Zeydel, Edwin H. 1927. "Ludwig Tieck's Library." Modern Language Notes 42: 21-25.

Zeydel, Edwin H. 1935. Ludwig Tieck, the German Romanticist. A Critical Study. Princeton: Princeton University Press.

Zweig, Stefan 1926. Ben Jonsons Volpone: eine lieblose Komödie in drei Akten. Postdam: Kiepenheuer Verlag.

How to cite this article:

Ribes Traver, Purificación. "Ludwig Tieck's Herr Von Fuchs (1793) As the Perfect

Embodiment of Romantic Irony." SEDERI 20 (2010): 121-142.

Author's contact: Purificacion.Ribes@uv.es

Submission: 07/07/2009

Acceptance: 03/12/2010 